\title{
Article \\ Synthesis of Ambient Cured GGBFS Based Alkali Activated Binder Using a Sole Alkaline Activator: A Feasibility Study
}

\author{
Thandiwe Sithole *, Nelson Tsotetsi and Tebogo Mashifana \\ Department of Chemical Engineering, University of Johannesburg, Doornfontein 2088, South Africa; \\ 216028491@student.uj.ac.za (N.T.); tmashifana@uj.ac.za (T.M.) \\ * Correspondence: nastassias@uj.ac.za; Tel.: +27-11-559-6815
}

\begin{abstract}
Utilisation of industrial waste-based material to develop a novel binding material as an alternative to Ordinary Portland Cement (OPC) has attracted growing attention recently to reduce or eliminate the environmental footprint associated with OPC. This paper presents an experimental study on the synthesis and evaluation of alkali activated Ground granulated blast furnace slag (GGBFS) composite using a $\mathrm{NaOH}$ solution as an alkaline activator without addition of silicate solution. Different $\mathrm{NaOH}$ concentrations were used to produce varied GGBFS based alkali activated composites that were evaluated for Uncofined Compressive Strength (UCS), durability, leachability, and microstructural performance. Alkali activated GGBFS composite prepared with $15 \mathrm{M} \mathrm{NaOH}$ solution at $15 \% \mathrm{~L} / \mathrm{S}$ ratio achieved a UCS of $61.43 \mathrm{MPa}$ cured for 90 days at ambient temperatures. The microstructural results revealed the formation of zeolites, with dense and non-porous morphology. Alkali activated GGBFS based composites can be synthesized using a sole alkaline activator with potential to reduce $\mathrm{CO}_{2}$ emission. The metal leaching tests revealed that there are no potential environmental pollution threats posed by the synthesized alkali activated GGBFS composites for long-term use.
\end{abstract}

Mashifana, T. Synthesis of Ambient Cured GGBFS Based Alkali Activated Binder Using a Sole Alkaline Activator: A Feasibility Study. Appl. Sci. 2021, 11, 5887. https://doi.org/ 10.3390/app11135887

Academic Editors: Chiara Giosuè,

Maria Letizia Ruello and

Alessandra Mobili

Received: 30 April 2021

Accepted: 1 June 2021

Published: 24 June 2021

Publisher's Note: MDPI stays neutral with regard to jurisdictional claims in published maps and institutional affiliations.

Copyright: (c) 2021 by the authors. Licensee MDPI, Basel, Switzerland. This article is an open access article distributed under the terms and conditions of the Creative Commons Attribution (CC BY) license (https:// creativecommons.org/licenses/by/ $4.0 /)$.

\section{Introduction}

The rapid growth of urban infrastructure developments and industrialization globally has created a huge demand and consumption of Ordinary Portland Cement (OPC), which contributes significantly to $\mathrm{CO}_{2}$ emissions [1,2]. The ever growing steel and iron industry results in a rapid generation of by-products (GGBFS) of about 300-350 Mt every year [3]. Worldwide cement manufacturing is projected to soar from 3.27 gigatons to 4.83 gigatons by 2030 and grow by $45 \%$ in 20 years, as compared to the present rate of production $[4,5]$. The current method used to produce OPC is energy intensive and emits an amount of $5-7 \%$ of global $\mathrm{CO}_{2}$ emissions, which deplete the ozone layer and causes global warming [5-7]. It also consumes a vast amount of natural resources such as fossil fuel and limestone, as 1 ton of cement requires about 2.8 tons of raw material, which then generates about 1 ton of $\mathrm{CO}_{2}[8,9]$. The $\mathrm{CO}_{2}$ emission footprint resulting from cement production is set to grow by 2.34 gigatons $(\mathrm{Gt}) \mathrm{CO}_{2}$ emissions in 2050 [5,10,11]. Hence, it is essential to develop alternative binding material to supplant OPC to minimise carbon dioxide emissions produced from the manufacturing of OPC and meet the sustainability requirements. Alkali activated binder is one of the innovations in replacing OPC which can be produced from waste materials such as mine tailings, iron slag foundry sand, fly ash, copper slag and granulated furnace slag with high alkaline activators, namely reactive silica, $\mathrm{NaOH}, \mathrm{KOH}$ and silicates solution [12-14]. The role of the alkaline activator is to form an alkali activated gel material by releasing the Si and $\mathrm{Al}$ ions from the precursor and breaking the Si-O-Al, Si-O-Si and Al-O-Al bonds to the solution $[15,16]$. Alkali activated materials (AAMs) have excellent attributes and mechanical properties such as high mechanical strength, excellent fire resistance, and low and energy saving liquid limits and shrinkages during production 
compared to OPC production [17]. Although AAMs have the above-mentioned excellent mechanical and geotechnical properties, the environmental impact associated with them is highly dependent on the type of precursor material and the alkaline activator used [18]. According to previous studies in alkali activated materials the combination of alkalis and silicates possess high activation potential that produce AAMs with excellent mechanical properties [15]. Alkali activated materials using a combination of $\mathrm{NaOH}$ and $\mathrm{NaSiO}_{3}$ as alkaline activators is a well-established research that is reported in the literature. Murri et al. [19] demonstrated the feasibility to develop alkali activated granulated blast furnace slag-based binder using sodium silicate and sodium hydroxide as alkaline activators with a maximum strength of $44 \mathrm{MPa}$. Rafeet et al. [20] found that the UCS of AAM made with GGBFS and fly ash-cured at ambient temperature reached $77 \mathrm{MPa}$ after 90 days curing [20]. Temuujin et al. [21] reported that AMMs prepared using GGBFS as a precursor and $\mathrm{NaOH} / \mathrm{NaSiO}_{3}$ solution yielded a UCS of $70 \mathrm{MPa}$ after 28 days of curing at ambient temperatures. Mejia et al. [22] found that the UCS of AAMs prepared with fly ash, GGBFS, and $\mathrm{Na}_{2} \mathrm{SiO}_{3}$ as an activating agent, cured at ambient temperature for 7 days, reached up to $40 \mathrm{MPa}$. Mejia et al. [22] further demonstrated the feasibility of developing GGBFS/ metakaolinite based AAMs using silica source and sodium hydroxide as activating agents; a maximum UCS of $60 \mathrm{MPa}$ was attained by curing at room temperature for 28 days. Zivica [23] produced an alkaline activated binary cement (GGBFS and OPC) and activated it with $\mathrm{NaOH}$ and silica fume; mortars produced UCS from 10 to $45 \mathrm{MPa}$ after 90 days of curing at room temperature [23]. Allahverdi et al. [24] blended Taftan pumice (95\%) and GGBFS (5\%), and used a combination of $\mathrm{NaOH}$, and $\mathrm{Na}_{2} \mathrm{SiO}_{3}$ to achieve a UCS between 30 and $36 \mathrm{MPa}$. The above-mentioned previous work shows that AAM derived from industrial waste has excellent mechanical strength using a combination of $\mathrm{NaSiO}_{3}$ and $\mathrm{NaOH}$. Alkali silicates $\left(\mathrm{NaSiO}_{3}\right)$ are expensive and have higher $\mathrm{CO}_{2}$-equivalent emission than that of OPC, in terms of production [15,25]. Hence the utilization of AAM as compared to OPC has been limited to a small scale. Previous studies reported that sodium silicate is a more environmentally unfriendly solution than $\mathrm{NaOH}$ in terms of its carbon footprint [26]. Therefore, there is a need to investigate the use of the eco-friendly activating agent $\mathrm{NaOH}$ as a solo activating agent to synthesise AAM with excellent mechanical strength. Sithole et al. [15] investigated the possibility of using $\mathrm{NaOH}$ as a sole activating agent to synthesize alkali activated GGBFS composites at elevated temperatures. The developed geopolymer yielded a durable brick with UCS of $72 \mathrm{MPa}$. Furthermore, Sithole et al. [13] successfully developed BOFS based AAMs using a sole alkaline activator. The author then investigated the mechanical properties of BOFS/FA based AAMs using sodium hydroxide as an activating agent. The results showed that developed BOFS/FA AAMs met the minimum requirement as per ASTM C34-13, C129-14a and SANS227: 2007 [9]. Nadoushan [27] blended Taftan pumice $(75 \%)$ and GGBFS (25) and then cured it for 28 days at ambient temperature. $\mathrm{KOH}$ and $\mathrm{NaOH}$ solutions were used activating agents; a UCS of up to $55 \mathrm{MPa}$ was achieved [27]. Falayi et al. [28] studied the feasibility of using FeCr slag as a precursor and $\mathrm{KOH}$ as an alkaline activator; an alkali activated FeCr slag with a UCS of $24.5 \mathrm{MPa}$ was developed. In another study Falayi et al. [29] reported that it is feasible to produce BOFS/GMT or Fly Ash/ GMT based AAMs that have good mechanical properties and are environmentally friendly. Most research reported in literature on alkali activated material use both $\mathrm{NaSiO}_{3}$ and $\mathrm{NaOH}$ as activating agents. There is scarce and not well documented literature on using a sole alkali activator without addition of sodium silicate or silica reactive instead of a combination of silica and alkali solutions. Furthermore, many documented studies continue to investigate alkali activated binder cured at elevated temperature of which for a country like South Africa (SA) that is facing severe energy crisis. This practice can cause power cuts; the use of elevated temperatures will put more strain on the energy grid on a production scale. Furthermore, the concept of alkali activated material in SA has not gained much traction to date due to the expense of alkali activating agents such as $\mathrm{NaSiO}_{3}$ as compared to $\mathrm{NaOH}$. It is with this in mind that this study was pursued to demonstrate the feasibility to synthesize alkali activated GGBFS using $\mathrm{NaOH}$ as an alkali activator 
without addition of sodium silicate or silica reactive to produce green and sustainable alkali activated GGBFS composites cured at ambient temperatures to save energy. This study aims to produce a sustainable alkali activated GGBFS cured at ambient temperatures using a $\mathrm{NaOH}$ as an activating agent, without an addition of any silica reactive source or solutions. The dissolution of alumino-silicates from the GGBFS as a precursor under different $\mathrm{NaOH}$ concentrations was studied. The synthesised alkali activated GGBFS were evaluated for mechanical strength, durability, and microstructural performance. To establish the most favourable condition for geo-synthesis of GGBFS the following parameters were investigated: molarities of $\mathrm{NaOH}$ ranging from 5 to $15 \mathrm{M}$; the liquid to solid ratio (from $20 \%$ to $30 \%$ ); the curing age $(7,28,56$ and 90 days). Lastly, the environmental effects of the synthesized alkali activated GGBFS geopolymer was also studied through 30 days of metal leachability testing.

\section{Materials and Methods}

\subsection{Materials}

GGBFS was obtained from a South African steel manufacturing firm and was used as a as an aluminosilicate source. $\mathrm{NaOH}$ with $96 \%$ purity was used as an activating agent in this study and was supplied byRochelle Chemicals, Johannesburg, SA. The GGBFS was pulverized to increase the surface area of the aluminosilicates to a median particle size of D50 $\leq 45 \mu \mathrm{m}$ as shown in Figure 1. The chemical and physical properties of GGBFS are shown in Table 1. The oxide composition demonstrates that GGBFS has a high content of $\mathrm{CaO}$ and $\mathrm{SiO}_{2}$. The XRD pattern in Figure 2 shows that GGBFS is amorphous with a hump at $20^{\circ}-40^{\circ}$; quartz and magnetite were the main identified phases. The XRD qualitative analyses showed that GGBFS is composed of $98 \%$ amorphous silica, which has been reported to have a faster reaction to silica compared with that of crystalline silica [30].

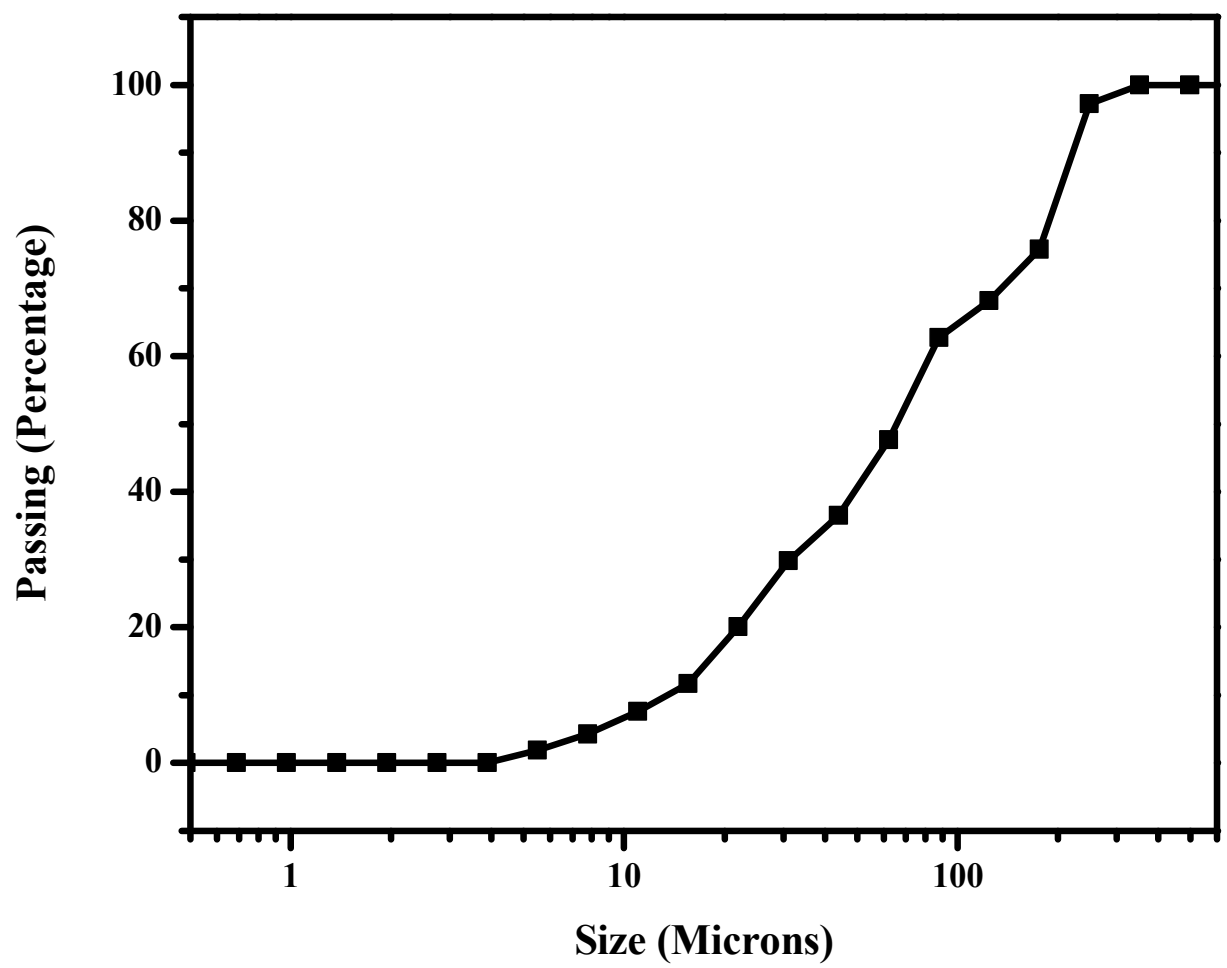

Figure 1. Particle size distribution of GGBFS. 
Table 1. Chemical and physical properties of raw GGBFS.

\begin{tabular}{cc}
\hline Chemical Composition (\%) & GGBFS \\
\hline $\mathrm{Na}_{2} \mathrm{O}$ & 0.21 \\
$\mathrm{MgO}$ & 5.48 \\
$\mathrm{Al}_{2} \mathrm{O}_{3}$ & 10.7 \\
$\mathrm{SiO}_{2}$ & 27.2 \\
$\mathrm{P}_{2} \mathrm{O}_{5}$ & 0.01 \\
$\mathrm{SO}_{3}$ & 2.19 \\
$\mathrm{Cl}$ & 0.02 \\
$\mathrm{~K}_{2} \mathrm{O}$ & 0.67 \\
$\mathrm{CaO}$ & 49.1 \\
$\mathrm{TiO}_{2}$ & 0.97 \\
$\mathrm{Cr}_{2} \mathrm{O}_{3}$ & 0.08 \\
$\mathrm{MnO} \mathrm{Fe}_{2} \mathrm{O}_{3}$ & 1.47 \\
$\mathrm{NiO}^{\mathrm{SrO}}$ & 1.22 \\
$\mathrm{Y}_{2} \mathrm{O}_{3}$ & 0.01 \\
$\mathrm{ZrO}_{2}$ & 0.29 \\
$\mathrm{BaO}_{\text {Loss of ignition }}$ & 0.02 \\
Specific gravity & 0.1 \\
Median particle size $(\mu \mathrm{m})$ & 0.3 \\
& 0.23 \\
& 2.91 \\
\hline
\end{tabular}

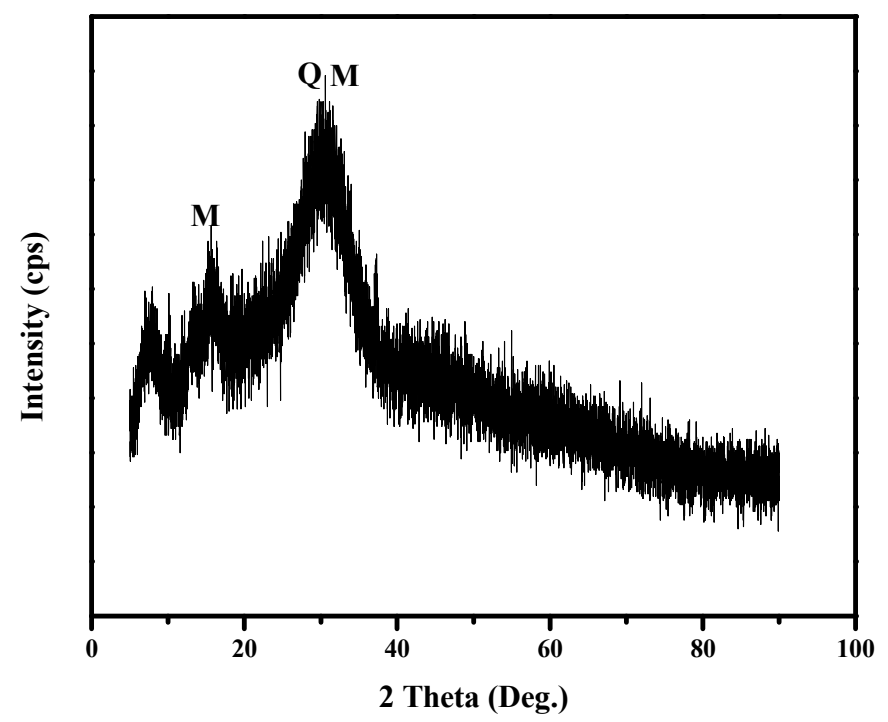

Figure 2. X-ray Diffraction analysis of GGBFS ( $Q=$ quartz, $M=$ magnetite).

\subsection{Equipment}

The chemical compositions of GGBFS before and after alkaline activation were analysed by the Rigaku ZSX Primus II (Applied Rigaku Technologies, Austin, TX, USA). The minerology and quantification were determined by X-ray Diffraction. The synthesized composites were carbon coated and mounted onto a scanning electron microscope for particle morphology determination using a Tescan Vega 3 XMU machine (Tescan Orsay Holding, Brno, Czech Republic). The unconfined compressive strength of the alkali activated GGBFS specimens were analysed using a cyber plus compression machine (Matest S.p.A, Treviolo, Italy). Particle size distribution was conducted using a Microtrac particle size analyser (Microtrac MRB, Osaka, Japan). The potential toxic leachates were determined using an Inductively Coupled Plasma-Optical emission spectrometer (ICP) (Thermo Fisher Scientific, Waltham, MA, USA). 


\subsection{Preparations of Alkali Activated GGBFS to Determine the Optimum Curing Conditions}

To establish the optimum curing conditions to investigate the effect of curing age on UCS, $\mathrm{NaOH}$ flakes were added to the deionized water to prepare varied $\mathrm{NaOH}$ solutions with concentrations of 5, 10, 15, 20, 25 and 30, as shown in Table 2. The alkali activated pastes were prepare by blending $\mathrm{NaOH}$ solutions with GGBFS until homogeneity was attained. The pastes were poured into $50 \times 50 \times 50 \mathrm{~mm}^{3}$ moulds, compacted using a vibration table and then covered to avoid water evaporation after casting. The pastes were then wrapped with plastic to allow setting at ambient temperature. After 1 day, the samples were removed from the mould and cured in plastic bags at ambient temperatures. The workability of the paste was determined by varying the liquid/solid ratio from 15 to $30 \%$ as shown in Table 2. The mechanical strength was used as a determining factor to choose the best curing conditions. The optimum curing conditions (15 M NaOH solution and $15 \%$ $\mathrm{L} / \mathrm{S}$ ratio) were used to prepare pastes to investigate the effect of curing age $(7,14,28,56$ and 90 days) on mechanical strength.

Table 2. Mix design formulations and curing conditions.

\begin{tabular}{ccccccc}
\hline $\begin{array}{c}\text { Sample } \\
\text { ID }\end{array}$ & $\begin{array}{c}\text { GGBFS } \\
\mathbf{( 1 0 0 \% )}\end{array}$ & $\begin{array}{c}\text { Concentration } \\
\mathbf{( M )}\end{array}$ & $\begin{array}{c}\text { NaOH } \\
\mathbf{( M P a )}\end{array}$ & L/S & $\begin{array}{c}\text { Temperature } \\
\left.\mathbf{(}{ }^{\circ} \mathbf{C}\right)\end{array}$ & $\begin{array}{c}\text { Curing Age } \\
\text { (Days) }\end{array}$ \\
\hline M1 & 100 & 5 & 26.52 & 0.2 & Ambient & 7 \\
M2 & 100 & 10 & 31.30 & 0.2 & Ambient & 7 \\
M3 & 100 & 15 & 40.27 & 0.2 & Ambient & 7 \\
M4 & 100 & 20 & 36.42 & 0.2 & Ambient & 7 \\
M5 & 100 & 25 & 30.25 & 0.2 & Ambient & 7 \\
M6 & 100 & 15 & 48.37 & 0.15 & Ambient & 7 \\
M7 & 100 & 15 & 40.27 & 0.20 & Ambient & 7 \\
M8 & 100 & 15 & 38.37 & 0.25 & Ambient & 7 \\
M9 & 100 & 15 & 35.03 & 0.30 & Ambient & 7 \\
M10 & 100 & 15 & 48.37 & 0.15 & Ambient & 7 \\
M11 & 100 & 15 & 53.47 & 0.15 & Ambient & 14 \\
M12 & 100 & 15 & 58.45 & 0.15 & Ambient & 28 \\
M13 & 100 & 15 & 60.48 & 0.15 & Ambient & 56 \\
M14 & 100 & 15 & 61.43 & 0.15 & Ambient & 90 \\
\hline
\end{tabular}

\subsection{Unconfined Compressive Strength (UCS) Testing}

The 7, 14, 28, 56 and 90 days cured specimens were placed between the two plates of a cyber-compression machine with maximum load of $1.0 \mathrm{MPa} / \mathrm{s}$. The load applied on the samples was displaced at a rate of $2 \mathrm{~mm} / \mathrm{min}$ until the limit of UCS was reached and the geopolymers failed.

\subsection{Metal Leachability of the AAMs}

The metal leachability test analysis was carried out using the toxicity characteristic leaching procedure (TCLP) tests (TCLP) procedure under USEPA method 1311. The synthesized Alkali Actiavted GGBFS composites were placed in a column that was entirely enclosed with extraction buffer. Sodium acetate and acetic acid of the required $\mathrm{pH}$ level of $4.93 \pm 0.05$ was used. The extraction process was conducted for 30 days. After 30 days, the leached metal concentrations were analysed by ICP using a 175 Inductively Coupled Plasma-Optical emission spectrometer (ICP) (Thermo Fisher Scientific, Waltham, MA, USA).

\subsection{Determination of Open Porosity, Volume of Permeable Pores and Absorption Rate}

The composite cured at optimum conditions was weighed and soaked in deionized water for 30 days. After 30 days the composites were taken out of the water and wiped to 
remove any visible water. Thereafter, the composite was weighed. Open porosity, $\mathrm{f}$, was then calculated using Equation (1) according to ASTM C373-14:

$$
\mathrm{f}=\frac{\mathrm{Ws}-\mathrm{Wd}}{\mathrm{V} \alpha}
$$

where Ws is the mass of the soaked composite in grams, Wd is the mass of the composite before soaking in water, $\mathrm{V}$ is the volume of the composite and $\alpha$ is the density of water. The volume of permeable pores was determined according to ASTM C 642-06.

\section{Results}

\subsection{Unconfined Compressive Strength}

\subsubsection{Effect of $\mathrm{NaOH}$ Concentration}

Figure 3 Shows the effect of variation of $\mathrm{NaOH}$ solution concentrations on UCS for specimens cured for 7 days. Increasing the $\mathrm{NaOH}$ solution concentration from 5 to $15 \mathrm{M}$ results in an increase in UCS of the alkali activated GGBFS based composites. The increasing trend is mainly due to higher degree of silica and alumina leaching [31]. The optimum concentration of $\mathrm{NaOH}$ solution was $15 \mathrm{M}$ : sample ID M3 where the highest UCS of 40.27 MPa was achieved as shown in Table 2. Increasing the $\mathrm{NaOH}$ solution concentration from 20 to $25 \mathrm{M}$ in sample M4 to M5 shown in Table 2 results in a reduction in UCS. This might be attributed to the thickening of solution that caused the mobility of ions from the aluminosilicate source to be lower and arrests further leaching out of ions [32]. In addition, it was observed that at higher concentration the alkali activated paste tends to be less workable, resulting in reduction of the dissolution rate of the alkaline activation process attributing an increase in congelation of silica and an increase in efflorescence risk [27,32]. Similar trends were reported by $[13,15,27]$. The optimum $\mathrm{NaOH}$ concentration was used to investigate the effect of the liquid to solid ratio.

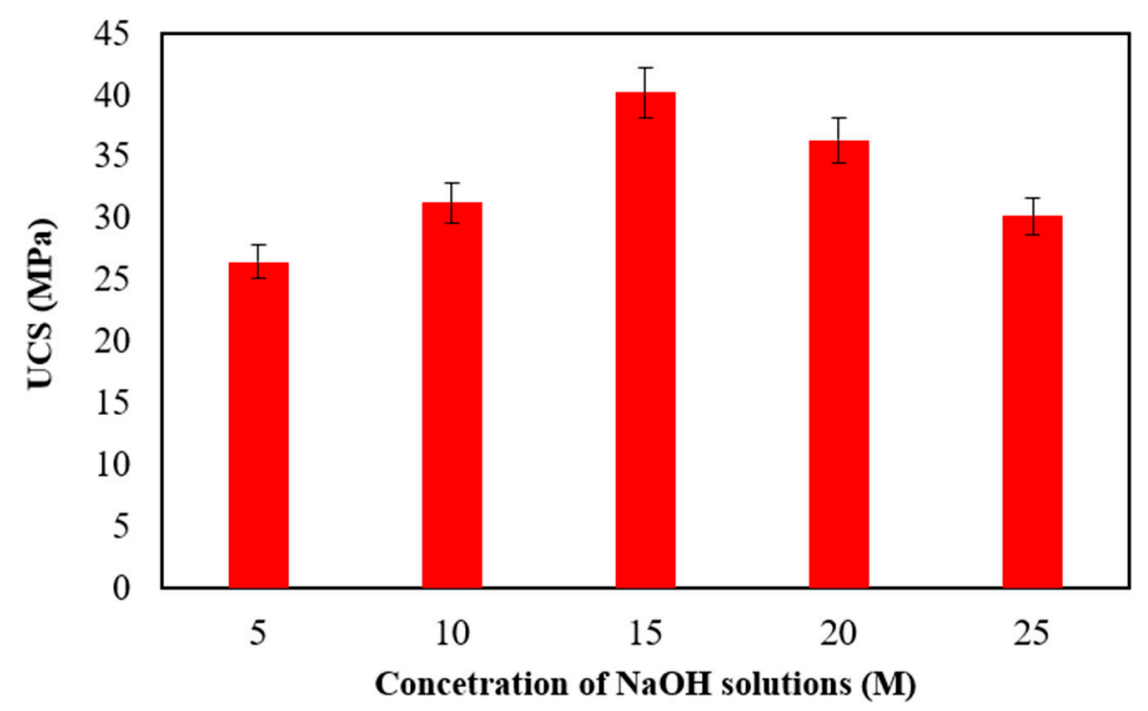

Figure 3. The effect of variation of $\mathrm{NaOH}$ solution concentration on UCS.

\subsubsection{Effect of Liquid-Solid Ratio}

Figure 4 shows the effect of varying the liquid to solid ratio from 15 to $30 \%$ on UCS. Alkali activated pastes prepared with 15\% liquid to solid ratio (Sample M6) had the most favourable workability which yielded a UCS of up to $48.4 \mathrm{MPa}$. This could be due to the homogeneity of the paste at 15\% that allows dissolution of Si and Al from GGBFS while the polycondensation is not hindered during the GGBFS alkaline activation process [33]. Reducing the liquid to solid ratio to $10 \%$ resulted in a paste of low workability which was impossible to cast. The UCS decreased by $28 \%$ when the L/S ratio was increased to $30 \%$ because the paste had a low gelation and exhibited segregation making it difficult to mould, 
and it also had a low workability, making it difficult to compact. [34,35]. Moreover, an increased L/S ratio beyond optimal (Sample M7-M9 in Table 2) reduces the number of larger pores in the hardened paste, resulting in a reduction in the mechanical properties of the alkali activated GGBFS specimens [35]. Previous work $[9,15,25,27,36]$ demonstrated that increasing L/S results in a poorer alkaline atmosphere; the degree of alkaline activation and the formation of a gel decreases and causes mechanical performance deterioration [35]. The L/S ratio also has effects on the morphology of Interfacial transition zone (ITZ) between the aggregates and the alkali activated GGBFS binder. This may be due to increased water evaporation during the curing of alkali activated pastes with high L/S ratios, which causes the binders to shrink significantly. Furthermore, a higher L/S signifies a heterogeneous distribution of ITZ around the aggregate surface $[37,38]$.

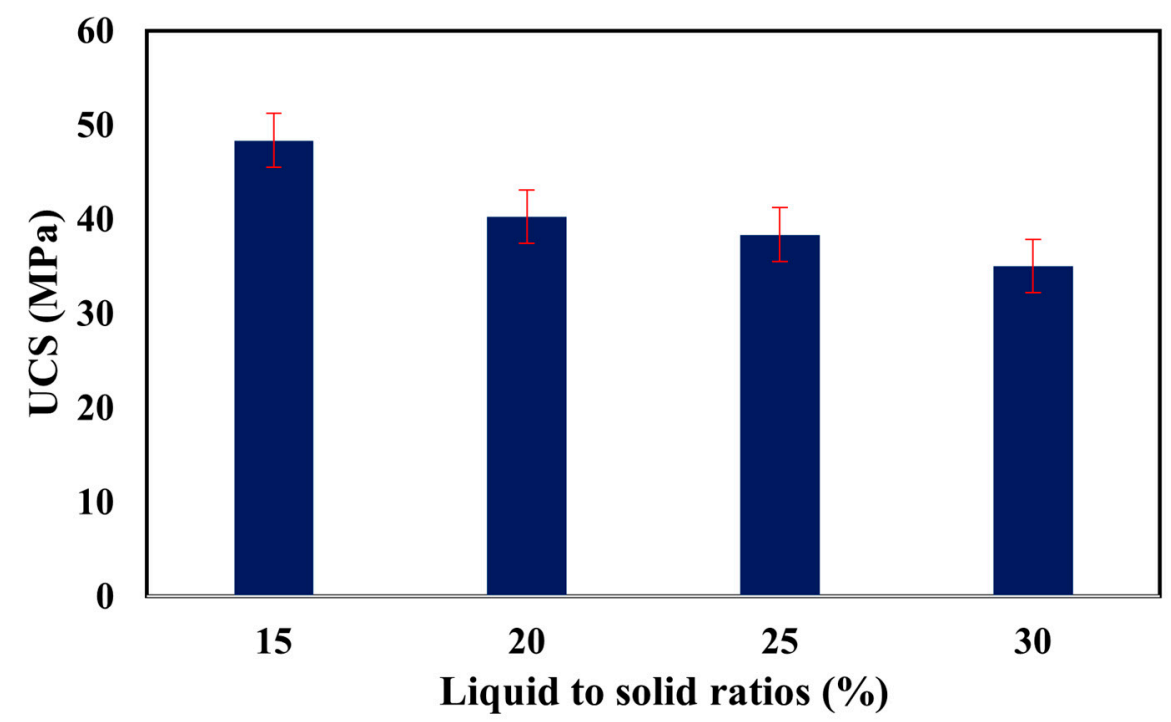

Figure 4. Effect of liquid-solid ratio on UCS.

\subsubsection{Effect of Curing Age at Ambient Temperature}

Figure 5 presents the unconfined compressive strength after 7, 14, 28, 56 and 90 days of curing GGBFS activated with $15 \mathrm{M} \mathrm{NaOH}$ solution at a liquid to solid ratio of $15 \%$. It is observed that the curing period plays a vital role in UCS development. A linear relationship is found to exist between the development of unconfined compressive strength and the curing period. From 7 to 90 days curing period there is a 27\% increase in UCS. Das et al. [39] reported similar findings. This is possibly due to increasing the curing period extent of dissolution of aluminosilicate species and an acceleration of the formation of a hardened specimen particularly in the initial stage of the alkaline activation process. There was a balance between $\mathrm{Si}, \mathrm{Al}$ and $\mathrm{Na}$ contents that allowed unreacted GGBFS particles to react with the alkaline solution with increasing curing period [40]. The stable reaction products formed with extended curing resulted in denser microstructure with better mechanical performance and improved UCS $[40,41]$. In addition, the $\mathrm{SiO}_{2} / \mathrm{Al}_{2} \mathrm{O}_{3}$ molar ratio may be within the required threshold causing the higher amounts of soluble silica (Si-O-) and $\mathrm{Na} 2 \mathrm{O}$. It is noticeable a large portion compressive strength is gained within 56 days. After 56 days, the statistical ANOVA test shown in Table 3 reveals that the UCS gained within 90 days is insignificantly different compared to the UCS gained within 56 days. This may have resulted in rapid generation of reaction products with time allowed for the unreacted GGBFS to further react with the $\mathrm{NaOH}$ solution attributed to an almost complete alkaline activation process at 90 days curing period. 


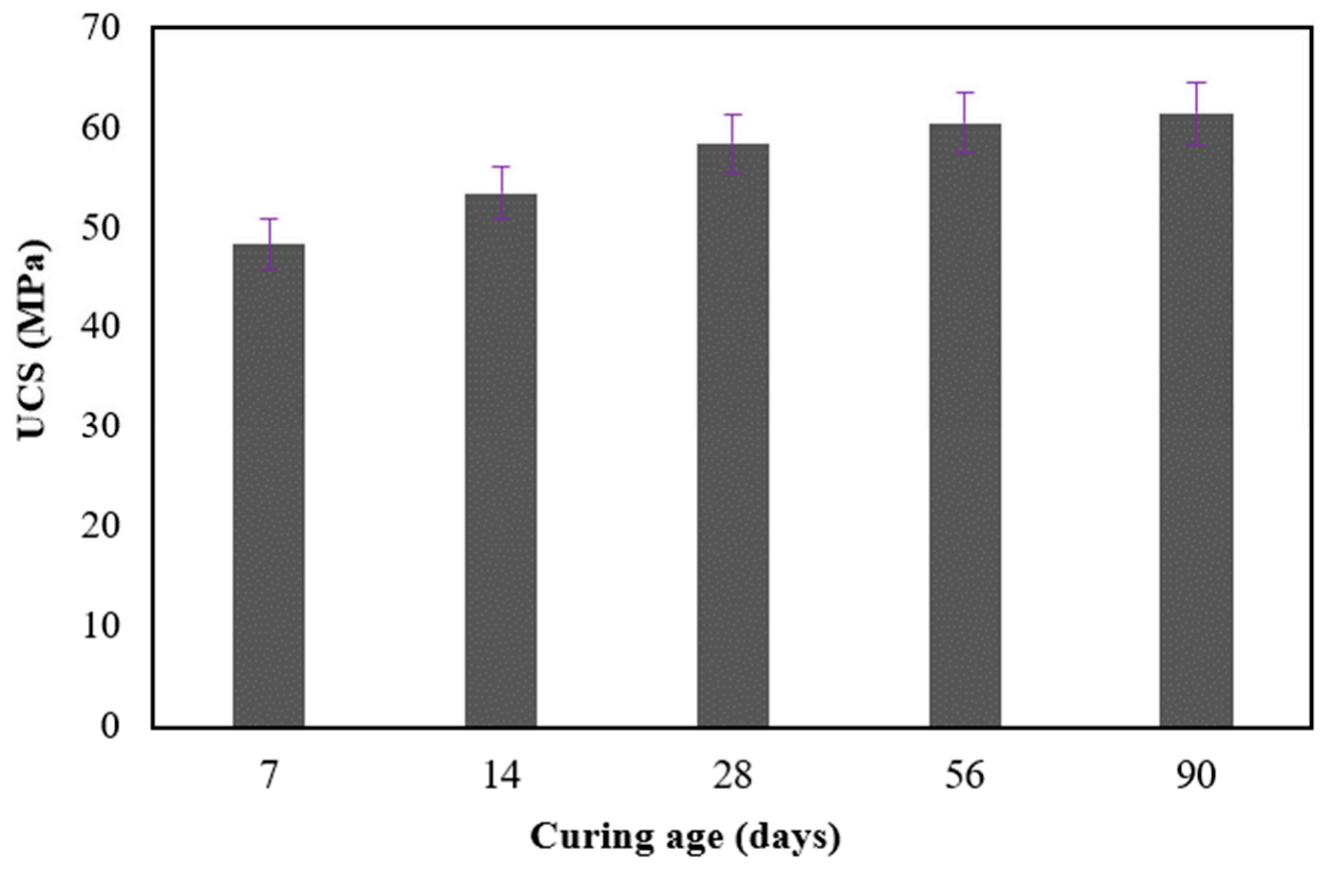

Figure 5. Effect of curing age at ambient temperature on UCS.

Table 3. Statistical single ANOVA test.

\begin{tabular}{ccccccc}
\hline Source of Variation & SS & df & MS & F & $p$-Value & F Crit \\
\hline Between Groups & 0 & 1 & 0 & 0 & 1 & 18.51282 \\
Within Groups & 0.9025 & 2 & 0.45125 & & & \\
Total & 0.9025 & 3 & & & & \\
\hline
\end{tabular}

\subsection{XRD Analysis of Samples with a Variation of Curing Period}

Figure 6 depicts the XRD patterns of samples cured at ambient temperature for different numbers of days. The XRD spectrum of GGBFS shows amorphous phases of quartz and magnetite around 29-30 . However, there is a considerable change in the crystallinity index of the composite after 28 days of curing, which reveals a significant strength development of the composites which explains the high UCS cured between 28 and 90 days as compared to specimens cured at 7 and 14 days. This result supports and agrees with discussions in Section 3.1.3. The XRD patterns of samples cured at ambient temperature revealed the presence of ettringite, quartz, $\mathrm{CSH}, \mathrm{CAH}$, hydrocalumite and calcite phases [40]. These are identified as the main hydration products formed during the alkaline activation process. However, the XRD patterns of specimens cured at 56 and 90 days show a diverse intensity especially around $2 \theta=5-10^{\circ}$, suggesting a great deal of variety in the alkaline activation process [42]. The variations in the chemical structure of the gels over the time indicated variation of cementitious products present at this curing age. These results are in line with previous work published by Nath [43]. This confirms that most of the reaction products were consumed during the alkali activation process, resulting in further improved mechanical properties and UCS [8,39]. 


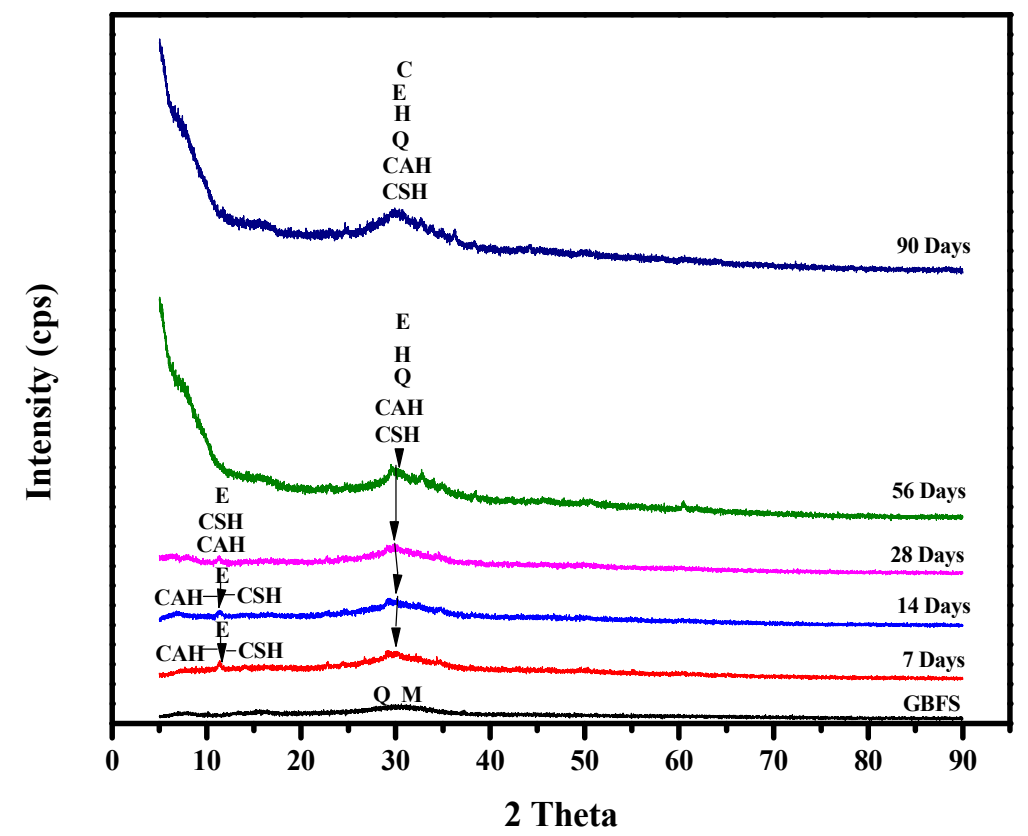

Figure 6. $\mathrm{XRD}$ pattern of samples $(\mathrm{M}=$ magnetite, $\mathrm{Q}=$ quartz, $\mathrm{H}=$ hydrocalumite, $\mathrm{CSH}=$ calcium silicate hydrate, $\mathrm{CAH}=$ calcium aluminate hydrate, $\mathrm{C}=$ calcite, $\mathrm{E}=$ ettringite).

\subsection{Effect of Curing Age (Days) on the Morphology}

Figure 7 depicts the SEM micrographs of GGBFS and samples cured at ambient temperature for different days. The morphology of GGBFS is non-homogeneous and distinctly porous [44]. Analyses of samples with different curing days show very different surface morphologies. The specimen micrograph with 7 days curing period showed a high quantity of unreacted particles, heterogeneous microstructure, and micro cracks. Similarly to the specimen micrograph cured for a period of 14 days, it also showed a presence of unreacted particles and micro cracks. This indicates a lower dissolution rate of GGBFS in the mix that caused incomplete activation process and lower UCS in the early stages of alkaline activation process. This could possibly be related to the high amount of silica that hindered the movement of reaction particles in the system, consequently, organic and inorganic phases improved polymerization reactions when reacted separately [43]. Organic and inorganic phase barriers became cracks, resulting in a weak connection of these two phases [45]. Also, much of alkaline solution used to achieve required workability may have evaporated, hence resulting in cracks as it formed pathways when escaping from the synthesized alkaline activated material [44-46]. On the other hand, fewer unreacted products and dense microstructure can be seen in a specimen cured for a period of 28 days. This indicates a higher dissolution rate of aluminosilicates in the alkaline activation mix and formation of more hydration products responsible for better mechanical properties [8]. The specimens cured for a period of 56 and 90 days showed an insignificant number of unreacted particles, traces of incomplete activation, coherent and much denser microstructure [47]. This clearly indicates the existence of greater hydration products due to a higher dissolution rate of GGBFS particles that optimized the formation of C-A-S-H and N-A-S-H products leading to compact microstructure and better mechanical properties. Das et al. also reported the same findings [39]. Moreover, the unreacted aggregates acted as inert aggregates, limiting the shrinkage of the samples during the hardening period, and reducing the number of cracks [47]. 

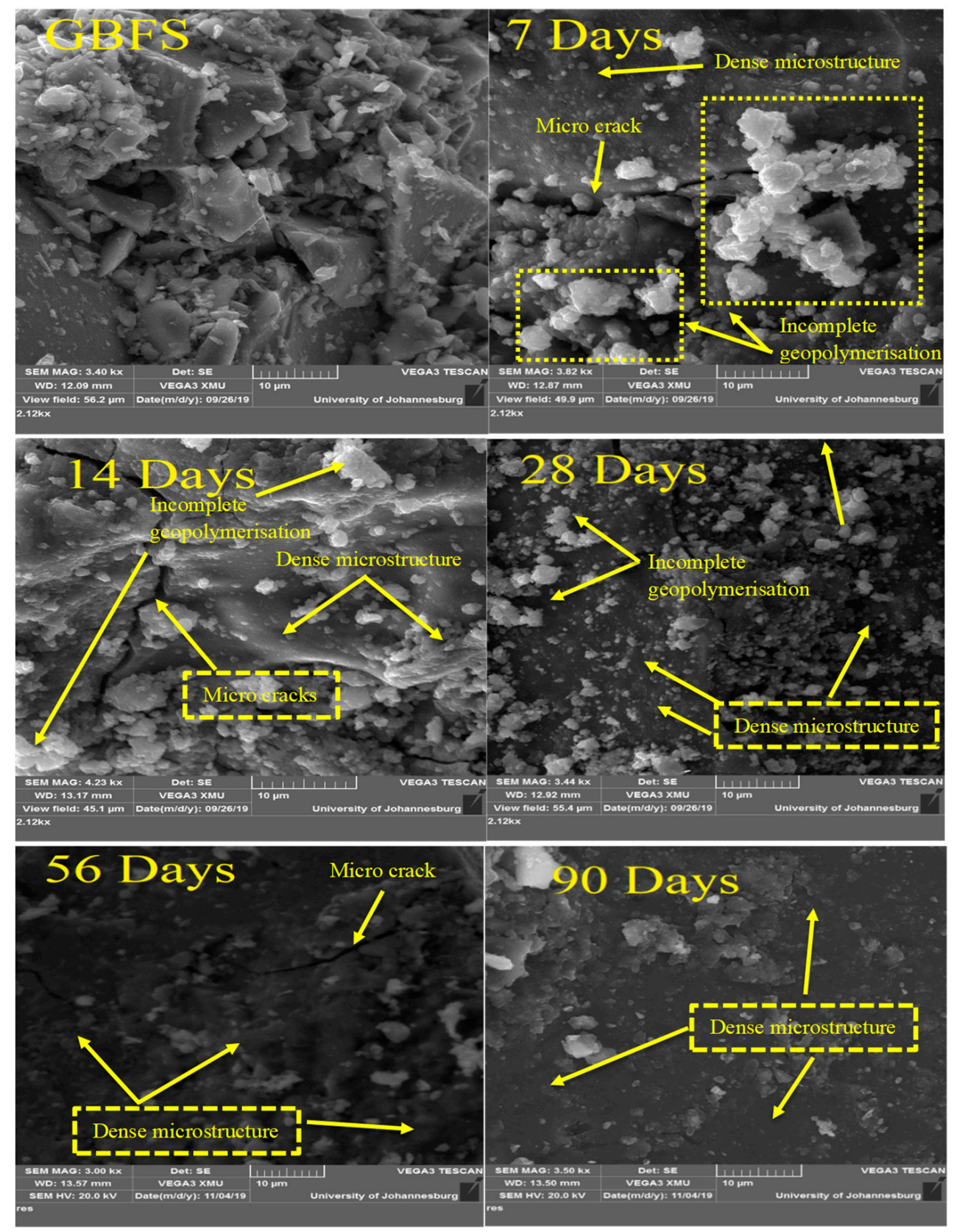

Figure 7. SEM micrographs of GGBFS and samples cured at ambient temperature for different days.

Table 4 shows the effect of water absorption and open porosity of the sample after 90 days of curing. The sample was immersed in deionised water for 30 days and the results revealed a low water absorption percentage that could be attributed to better alkali activated GGBFS composite within the matrix [15]. This was also corroborated by XRD and SEM analysis. In addition, the C-A-S-H phases within the alkali activated GGBFS composite matrix are highly water-bound [8]. The sample had a lower volume of permeable pores as compared to the $10 \%$ permeable limit suggested by Huseien [48]. The low volume of permeable pores shows that the sample has fewer capillary pores and air voids, which confirms low water absorption, better UCS and durability [49]. 
Table 4. 30 days-soaked alkali activated specimen properties.

\begin{tabular}{cc}
\hline 90 Days Ambient Cured Alkali Activated Sample & \\
\hline Mass of cast (g) & 278 \\
Mass of cast after 30 days soak (g) & 285 \\
UCS before soak (MPa) & 61.4 \\
UCS after soak (MPa) & 57.4 \\
\% water absorption & 2.64 \\
\% reduction in UCS & 6.92 \\
Open porosity & 0.079 \\
Volume of permeable pores (\%) & 9 \\
\hline
\end{tabular}

\subsection{Leachability}

Table 5 shows the leaching concentrations of potential toxic elements of raw GGBFS and ambient cured alkaline activated GGBFS at different curing periods. The leached heavy metal concentrations of all samples were insignificant and within the allowed USEPA limits recommended by Sithole et al. $[15,50]$. In addition, it is worth noting that the concentrations of heavy metals in the samples further reduced as the curing period increased, which may be due to the effective development of the activated matrix that immobilized heavy metals in three-dimensional CSH and CAH phases [51]. The TCLP results agree with the established literature that the alkaline activation process tends to immobilise and incorporated heavy metals into C-A-S-H phases as the compressive strength gains over time [52]. Therefore, the produced alkaline activated GGBFS composites have good chemical stability and do not have any potential environmental impact that could contaminate the environment if used over the long-term [53].

Table 5. Leachability of heavy metals concentration before and after alkaline activation.

\begin{tabular}{|c|c|c|c|c|c|c|c|}
\hline \multirow{3}{*}{ Constituents } & \multirow[b]{2}{*}{$\begin{array}{l}\text { Raw GGBFS } \\
\text { Concentration }\end{array}$} & \multirow[b]{2}{*}{$\begin{array}{c}\text { USEPA Maximum } \\
\text { Allowed Concentration } \\
\text { in Leachate }\end{array}$} & \multicolumn{5}{|c|}{ Specimen Cured Period } \\
\hline & & & 7 Days & 14 Days & 28 Days & 56 Days & 90 Days \\
\hline & $(\mathrm{ppm})$ & $(\mathrm{ppm})$ & $(\mathrm{ppm})$ & (ppm) & (ppm) & (ppm) & (ppm) \\
\hline $\mathrm{Cu}$ & 0.37 & 5 & 0.24 & 0.16 & 0.09 & 0.08 & 0.06 \\
\hline $\mathrm{Fe}$ & 0.04 & 10 & 0.03 & 0.03 & 0.021 & 0.019 & 0.01 \\
\hline $\mathrm{Mn}$ & 0.06 & 5 & 0.04 & 0.03 & 0.03 & 0.03 & 0.02 \\
\hline $\mathrm{Zn}$ & 0.01 & 0.1 & 0.01 & 0.01 & 0.01 & 0.01 & 0 \\
\hline $\mathrm{Ni}$ & 0.01 & 0.2 & 0.01 & 0 & 0 & 0 & 0 \\
\hline $\mathrm{Cr}$ & 0.09 & 5 & 0.09 & 0.08 & 0.08 & 0.07 & 0.02 \\
\hline $\mathrm{Pb}$ & 0.12 & 5 & 0.09 & 0.79 & 0.06 & 0.05 & 0.03 \\
\hline
\end{tabular}

\section{Conclusions}

The aim of this study was to investigate the feasibility of producing sustainable alkali activated GGBFS composites cured at ambient temperatures using $\mathrm{NaOH}$ solution as an activating agent, without addition of any silica reactive source. The effect of molarities of $\mathrm{NaOH}$ solution ranging from 5 to $15 \mathrm{M}$; the liquid to solid ratio (from $15 \%$ to $30 \%$ ); the curing age $(7,28,56$ and 90 days) and durability on the mechanical strength was investigated. Lastly, the optimum synthesised alkali activated GGBFS composites were evaluated for microstructural performance and potential environmental impacts using TCLP. Based on the findings of this research paper, the following conclusions can be drawn:

1. The mechanical strength of the alkali activated GGBFS composites is highly dependent on the concentration of the alkaline activator, curing period and the L/S ratio.

2. The most favourable condition to synthesize alkali activated GGBFS composites was a concentration of $15 \mathrm{M} \mathrm{NaOH}$ solution at a L/S ration of $15 \%$, cured for 90 days.

3. The long-term curing significantly improved the mechanical strength of the composites by achieving the highest UCS of $61.43 \mathrm{MPa}$ which is $27 \%$ higher compared to composites cured for a short term (sample M10). 
4. The synthesized composites did not have any potential environmental impacts as the leached heavy metal concentrations of all composites were insignificant and within the allowed USEPA limits.

5. The study also shows that alkali activated cementitious material can be synthesized by just using a sole alkaline activator without addition of a silica reactive source.

6. Using the mechanical strength criterion, the developed composites meet ASTM specifications for different applications in building and construction such as facing and solid masonry brick and pavement block and can be used as an alternative binding material.

7. Further studies on using the synthesized alkali activated composite should be tested as a binder to develop building and construction materials.

Author Contributions: Supervision, writing — original draft preparation, conceptualization, methodology, validation: T.S.; investigation, data curation. writing-original draft preparation: N.T.; cosupervision, conceptualization, writing — review and editing: T.M. All authors have read and agreed to the published version of the manuscript.

Funding: This research was funded by the National research foundation (ZA), grant number TTK180412320124 and the APC was funded by the University of Johannesburg.

Data Availability Statement: Data available within the text of this research paper.

Conflicts of Interest: The authors declare no conflict of interest. The funders had no role in the design of the study; in the collection, analyses, or interpretation of data; in the writing of the manuscript, or in the decision to publish the results.

\section{References}

1. Díaz, Y.C.; Berriel, S.S.; Heierli, U.; Favier, A.R.; Machado, I.R.S.; Scrivener, K.L.; Hernández, J.F.M.; Habert, G. Limestone calcined clay cement as a low-carbon solution to meet expanding cement demand in emerging economies. Dev. Eng. 2017, 2, 82-91. [CrossRef]

2. Zannerni, G.M.; Fattah, P.; Al-Tamimi, A.K. Ambient-Cured geopolymer concrete with single alkali activator. Sustain. Mater. Technol. 2020, 23, e00131. [CrossRef]

3. Robayo-Salazar, R.A.; De Gutiérrez, M.; Puertas, F. Study of synergy between a natural volcanic pozzolan and a granulated blast furnace slag in the production of geopolymeric pastes and mortars. Constr. Build. Mater. 2017, 157, 151-160. [CrossRef]

4. Nwankwo, C.O.; Bamigboye, G.O.; Davies, E.; Michaels, T.A. High volume Portland cement replacement: A review. Constr. Build. Mater. 2020, 260, 120445. [CrossRef]

5. Habert, G. Assessing the environmental impact of conventional and 'green'cement production. In Eco-Efficient Construction and Building Materials; Woodhead Publishing: Cambridge, UK, 2014; pp. 199-238.

6. Wi, K.; Lee, H.S.; Lim, S.; Song, H.; Hussin, M.W.; Ismail, M.A. Use of an agricultural by-product, nano sized palm oil fuel ash as a supplementary cementitious material. Constr. Build. Mater. 2018, 183, 139-149. [CrossRef]

7. Naqi, A.; Jang, J.G. Recent progress in green cement technology utilizing low-carbon emission fuels and raw materials: A review. Sustainability 2019, 11, 537. [CrossRef]

8. Shubbar, A.A.; Sadique, M.; Shanbara, H.K.; Hashim, K. The development of a new low carbon binder for construction as an alternative to cement. In Advances in Sustainable Construction Materials and Geotechnical Engineering; Springer: Singapore, 2020; pp. 205-213.

9. Sithole, N.T.; Okonta, F.; Ntuli, F. Mechanical properties and structure of fly ash modified basic oxygen furnace slag based geopolymer masonry blocks. J. Solid Waste Technol. Manag. 2020, 46, 372-383. [CrossRef]

10. Sanjuán, M.Á.; Andrade, C.; Mora, P.; Zaragoza, A. Carbon dioxide uptake by cement-based materials: A Spanish case study. Appl. Sci. 2020, 10, 339. [CrossRef]

11. Cement Sustainability Initiative. In Technology Roadmap: Low-Carbon Technology for the INDIAN Cement Industry; World Business Council for Sustainable Development and International Energy Agency: Geneva, Switzerland, 2013.

12. Singh, N.B.; Middendorf, B. Geopolymers as an alternative to Portland cement: An overview. Constr. Build. Mater. 2020, 237, 117-455. [CrossRef]

13. Sithole, N.T.; Okonta, F.; Ntuli, F. Development of lightweight construction blocks by alkaline activation of bof slag. J. Solid Waste Technol. Manag. 2019, 45, 175-185. [CrossRef]

14. Madani, H.; Ramezanianpour, A.A.; Shahbazinia, M.; Ahmadi, E. Geopolymer bricks made from less active waste materials. Constr. Build. Mater. 2020, 247, 118441. [CrossRef]

15. Sithole, N.T.; Mashifana, T. Geosynthesis of building and construction materials through alkaline activation of granulated blast furnace slag. Constr. Build. Mater. 2020, 264, 120712. [CrossRef] 
16. Mashifana, T.; Sithole, T. Recovery of silicon dioxide from waste foundry sand and alkaline activation of desilicated foundry sand. J. Sustain. Metall. 2020, 6, 700-714. [CrossRef]

17. Abdullah, M.M.; Ming, L.Y.; Yong, H.C.; Tahir, M.F. Clay-Based materials in geopolymer technology. In Cement Based Materials; InTech: London, UK, 2018; p. 239.

18. Bong, S.H.; Nematollahi, B.; Nazari, A.; Xia, M.; Sanjayan, J. Efficiency of different superplasticizers and retarders on properties of one-part' fly ash-slag blended geopolymers with different activators. Materials 2019, 12, 3410. [CrossRef]

19. Murri, A.N.; Rickard, W.D.A.; Bignozzi, M.C.; Van Riessen, A. High temperature behaviour of ambient cured alkali-activated materials based on ladle slag. Cem. Concr. Res. 2013, 43, 51-61. [CrossRef]

20. Rafeet, A.; Vinai, R.; Soutsos, M.; Sha, W. Effects of slag substitution on physical and mechanical properties of fly ash-based alkali activated binders (AABs). Cem. Concr. Res. 2019, 122, 118-135. [CrossRef]

21. Temuujin, J.V.; Van Riessen, A.; Williams, R. Influence of calcium compounds on the mechanical properties of fly ash geopolymer pastes. J. Hazard. Mater. 2009, 167, 82-88. [CrossRef]

22. Mejía, J.M.; de Gutiérrez, R.M.; Montes, C. Rice husk ash and spent diatomaceous earth as a source of silica to fabricate a geopolymeric binary binder. J. Clean. Prod. 2016, 118, 133-139. [CrossRef]

23. Živica, V. Effectiveness of new silica fume alkali activator. Cem. Concr. Compos. 2006, 28, 21-25. [CrossRef]

24. Allahverdi, A.; Mehrpour, K.; Kani, E.N. Investigating the possibility of utilizing pumice-type natural pozzonal in production of geopolymer cement. Ceram. Silik. 2008, 52, 16.

25. Falayi, T. Sustainable solidification of ferrochrome slag through geopolymerisation: A look at the effect of curing time, type of activator and liquid solid ratio. Sustain. Environ. Res. 2019, 29, 1-10. [CrossRef]

26. Tekin, I.; Gencel, O.; Gholampour, A.; Oren, O.H.; Koksal, F.; Ozbakkaloglu, T. Recycling zeolitic tuff and marble waste in the production of eco-friendly geopolymer concretes. J. Clean. Prod. 2020, 268, 122298. [CrossRef]

27. Nadoushan, M.J.; Ramezanianpour, A. The effect of type and concentration of activators on flowability and compressive strength of natural pozzolan and slag-based geopolymers. Constr. Build. Mater. 2016, 111, 337-347. [CrossRef]

28. Ma, C.; Long, G.; Shi, Y.; Xie, Y. Preparation of cleaner one-part geopolymer by investigating different types of commercial sodium metasilicate in China. J. Clean. Prod. 2018, 201, 636-647. [CrossRef]

29. Falayi, T. A comparison between fly ash-and basic oxygen furnace slag-modified gold mine tailings geopolymers. Int. J. Energy Environ. Eng. 2019, 1-11. [CrossRef]

30. Nematollahi, B.; Qiu, J.; Yang, E.H.; Sanjayan, J. Micromechanics constitutive modelling and optimization of strain hardening geopolymer composite. Ceram. Int. 2017, 43, 5999-6007. [CrossRef]

31. Part, W.K.; Ramli, M.; Cheah, C.B. An overview on the influence of various factors on the properties of geopolymer concrete derived from industrial by-products. Constr. Build. Mater. 2015, 77, 370-395. [CrossRef]

32. Samantasinghar, S.; Singh, S.P. Effect of synthesis parameters on compressive strength of fly ash-slag blended geopolymer. Constr. Build. Mater. 2018, 170, 225-234. [CrossRef]

33. Liew, Y.M.; Kamarudin, H.; Al Bakri, A.M.; Binhussain, M.; Luqman, M.; Nizar, I.K.; Ruzaidi, C.M.; Heah, C.Y. Influence of solids-to-liquid and activator ratios on calcined kaolin cement powder. Phys. Procedia 2011, 22, 312-317. [CrossRef]

34. Yahya, Z.; Abdullah, M.M.A.B.; Hussin, K.; Ismail, K.N.; Razak, R.A.; Sandu, A.V. Effect of solids-to-liquids, $\mathrm{Na}_{2} \mathrm{SiO}_{3}$-to-NaOH and curing temperature on the palm oil boiler ash ( $\mathrm{Si}+\mathrm{Ca}$ ) geopolymerisation system. Materials 2015, 8, 2227-2242. [CrossRef]

35. Peng, H.; Cui, C.; Cai, C.S.; Liu, Y.; Liu, Z. Microstructure and microhardness property of the interface between a metakaolin/GGGBFSbased geopolymer paste and granite aggregate. Constr. Build. Mater. 2019, 221, 263-273. [CrossRef]

36. Falayi, T.; Okonta, F.N.; Ntuli, F. Desilication of fly ash and development of lightweight construction blocks from alkaline activated desilicated fly ash. Int. J. Environ. Waste Manag. 2017, 20, 233-253. [CrossRef]

37. Imtiaz, L.; Rehman, S.K.U.; Ali Memon, S.; Khizar Khan, M.; Faisal Javed, M. A review of recent developments and advances in eco-friendly geopolymer concrete. Appl. Sci. 2020, 10, 7838. [CrossRef]

38. Kupaei, R.H.; Alengaram, U.J.; Jumaat, M.Z. The effect of different parameters on the development of compressive strength of oil palm shell geopolymer concrete. Sci. World J. 2014, 2014, 898536. [CrossRef] [PubMed]

39. Das, S.K.; Mustakim, S.M.; Adesina, A.; Mishra, J.; Alomayri, T.S.; Assaedi, H.S.; Kaze, C.R. Fresh, strength and microstructure properties of geopolymer concrete incorporating lime and silica fume as replacement of fly ash. J. Build. Eng. 2020, 32, 101780. [CrossRef]

40. Mahmoodi, O.; Siad, H.; Lachemi, M.; Dadsetan, S.; Sahmaran, M. Development of ceramic tile waste geopolymer binders based on pre-targeted chemical ratios and ambient curing. Constr. Build. Mater. 2020, 258, 120297. [CrossRef]

41. Zulkifly, K.; Cheng-Yong, H.; Yun-Ming, L.; Abdullah, M.M.a.B.; Shee-Ween, O.; Khalid, M.S.B. Effect of phosphate addition on room-temperature-cured fly ash-metakaolin blend geopolymers. Constr. Build. Mater. 2021, 270, 121486. [CrossRef]

42. Phummiphan, I.; Horpibulsuk, S.; Rachan, R.; Arulrajah, A.; Shen, S.-L.; Chindaprasirt, P. High calcium fly ash geopolymer stabilized lateritic soil and granulated blast furnace slag blends as a pavement base material. J. Hazard. Mater. 2018, 341, 257-267. [CrossRef]

43. Nath, S.K. Fly ash and zinc slag blended geopolymer: Immobilization of hazardous materials and development of paving blocks. J. Hazard. Mater. 2020, 387, 121673. [CrossRef] [PubMed]

44. Du, J.; Bu, Y.; Shen, Z.; Hou, X.; Huang, C. Effects of epoxy resin on the mechanical performance and thickening properties of geopolymer cured at low temperature. Mater. Des. 2016, 109, 133-145. [CrossRef] 
45. Lahoti, M.; Tan, K.H.; Yang, E.-H. A critical review of geopolymer properties for structural fire-resistance applications. Constr. Build. Mater. 2019, 221, 514-526. [CrossRef]

46. Chen, X.; Zhu, G.R.; Wang, J.; Chen, Q. Effect of polyacrylic resin on mechanical properties of granulated blast furnace slag based geopolymer. J. Non Cryst. Solids 2018, 481, 4-9. [CrossRef]

47. Patel, Y.J.; Shah, N. Development of self-compacting geopolymer concrete as a sustainable construction material. Sustain. Environ. Res. 2018, 28, 412-421. [CrossRef]

48. Huseien, G.F.; Mirza, J.; Ismail, M.; Hussin, M.W. Influence of different curing temperatures and alkali activators on properties of GGBFS geopolymer mortars containing fly ash and palm-oil fuel ash. Constr. Build. Mater. 2016, 125, 1229-1240. [CrossRef]

49. Furlani, E.; Maschio, S.; Magnan, M.; Aneggi, E.; Andreatta, F.; Lekka, M.; Lanzutti, A.; Fedrizzi, L. Synthesis and characterization of geopolymers containing blends of unprocessed steel slag and metakaolin: The role of slag particle size. Ceram. Int. 2018, 44, 5226-5232. [CrossRef]

50. Ali Shah, S.F.; Chen, B.; Ahmad, M.R.; Haque, M.A. Development of cleaner one-part geopolymer from lithium slag. J. Clean. Prod. 2021, 291, 125241. [CrossRef]

51. Sun, S.; Lin, J.; Fang, L.; Ma, R.; Ding, Z.; Zhang, X.; Zhao, X.; Liu, Y. Formulation of sludge incineration residue based geopolymer and stabilization performance on potential toxic elements. Waste Manag. 2018, 77, 356-363. [CrossRef]

52. Luhar, S.; Cheng, T.-W.; Nicolaides, D.; Luhar, I.; Panias, D.; Sakkas, K. Valorisation of glass wastes for the development of geopolymer composites-Durability, thermal and microstructural properties: A review. Constr. Build. Mater. 2019, 222, 673-687. [CrossRef]

53. ASTM Standard C642-13. In Standard Test Method for Density, Absorption, and Voids in Hardened Concrete; ASTM International: West Conshohocken, PA, USA, 2013. 